February 2004 - NREL/TP-620-35618

\title{
Utility Green Pricing Programs: Design, Implementation, and Consumer Response
}

Lori Bird, Blair Swezey, and Jørn Aabakken

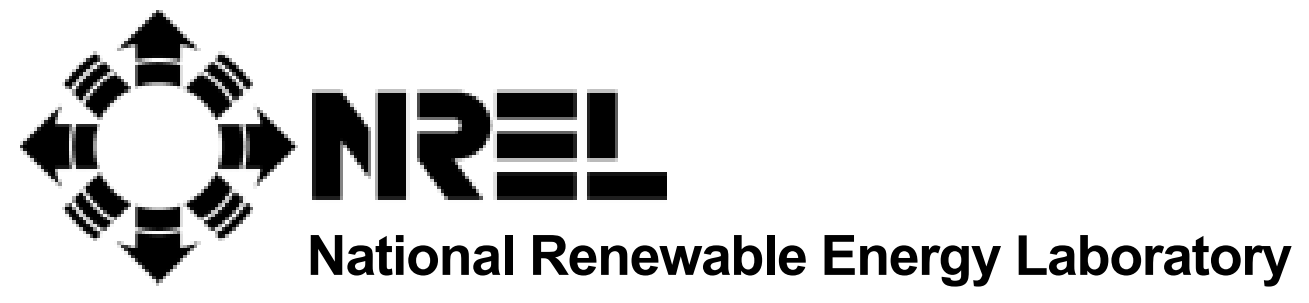

1617 Cole Boulevard

Golden, Colorado 80401-3393

NREL is a U.S. Department of Energy Laboratory Operated by Midwest Research Institute $\bullet$ Battelle

Contract No. DE-AC36-99-G010337 


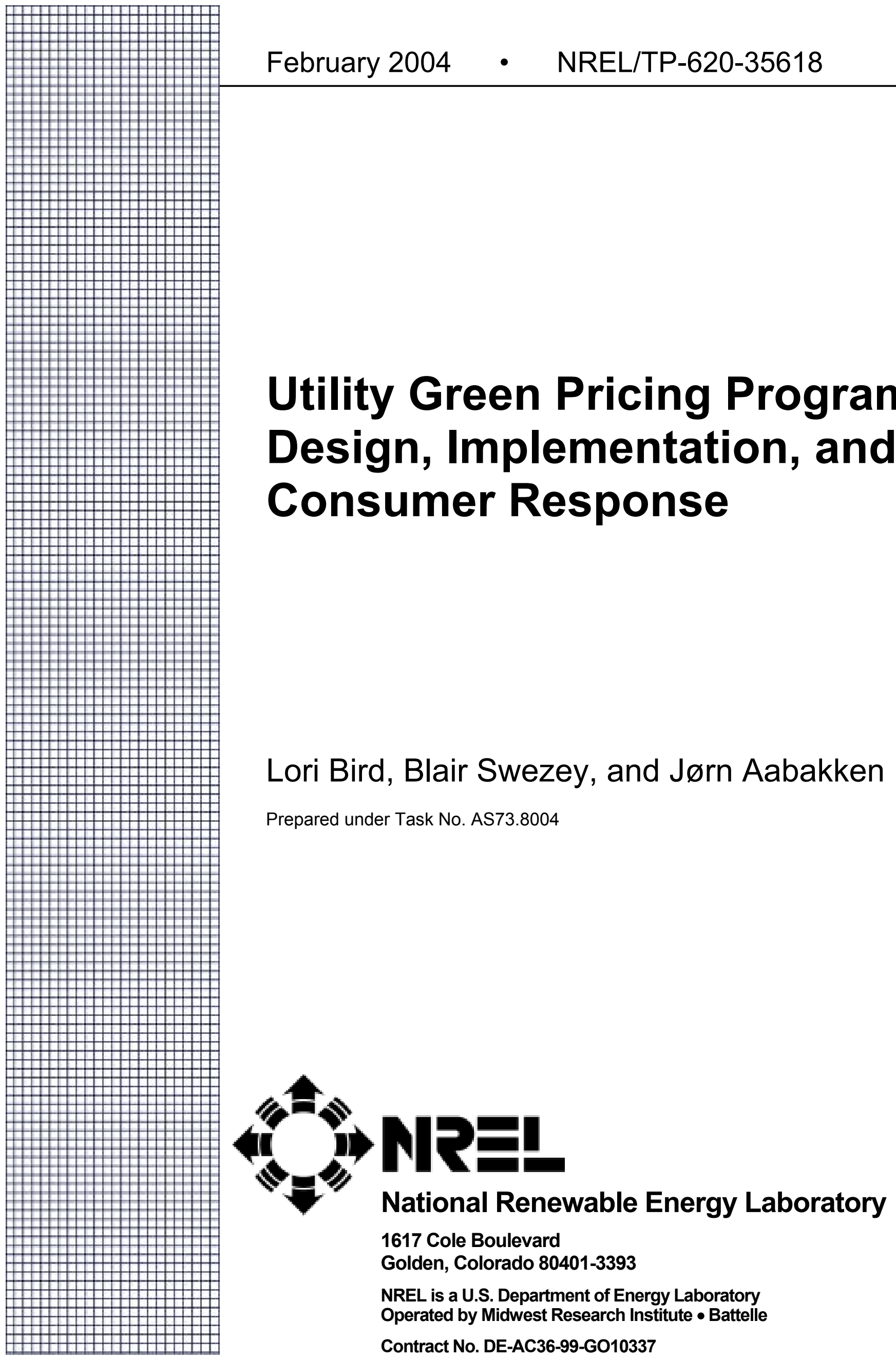




\section{NOTICE}

This report was prepared as an account of work sponsored by an agency of the United States government. Neither the United States government nor any agency thereof, nor any of their employees, makes any warranty, express or implied, or assumes any legal liability or responsibility for the accuracy, completeness, or usefulness of any information, apparatus, product, or process disclosed, or represents that its use would not infringe privately owned rights. Reference herein to any specific commercial product, process, or service by trade name, trademark, manufacturer, or otherwise does not necessarily constitute or imply its endorsement, recommendation, or favoring by the United States government or any agency thereof. The views and opinions of authors expressed herein do not necessarily state or reflect those of the United States government or any agency thereof.

Available electronically at http://www.osti.gov/bridge

Available for a processing fee to U.S. Department of Energy

and its contractors, in paper, from:

U.S. Department of Energy

Office of Scientific and Technical Information

P.O. Box 62

Oak Ridge, TN 37831-0062

phone: 865.576.8401

fax: 865.576 .5728

email: reports@adonis.osti.gov

Available for sale to the public, in paper, from:

U.S. Department of Commerce

National Technical Information Service

5285 Port Royal Road

Springfield, VA 22161

phone: 800.553.6847

fax: 703.605.6900

email: orders@ntis.fedworld.gov

online ordering: http://www.ntis.gov/ordering.htm 


\section{Acknowledgments}

This work was funded by the U.S. Department of Energy's (U.S. DOE) Office of Energy Efficiency and Renewable Energy (EERE). The authors thank Ryan Wiser of Lawrence Berkeley National Laboratory, Laura Vimmerstedt of the National Renewable Energy Laboratory (NREL), Ed Holt of Ed Holt and Associates, Adam Capage of Platts, and Dan Lieberman of the Center for Resource Solutions for their thoughtful review of the document; and Michelle Kubik of NREL for her editorial support. The authors also acknowledge the support of the EERE technology programs and of David McAndrew, EERE program manager. Finally, the authors thank the many utility green pricing program managers who have consistently provided the data presented in this report. 


\section{Table of Contents}

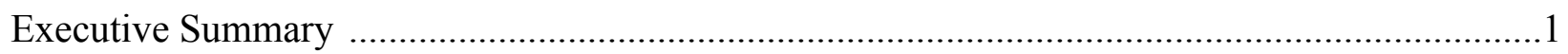

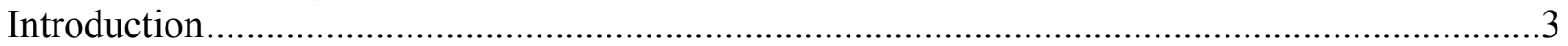

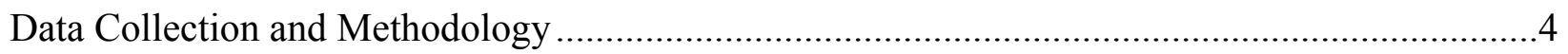

Customer Participation.......................................................................................................

Number of Customers ..........................................................................................

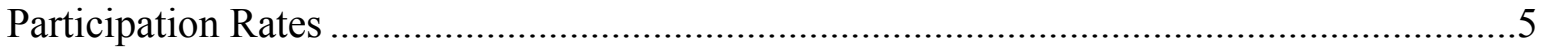

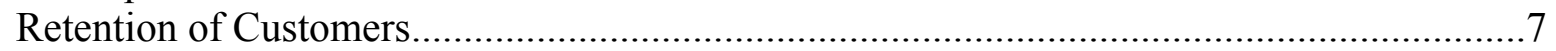

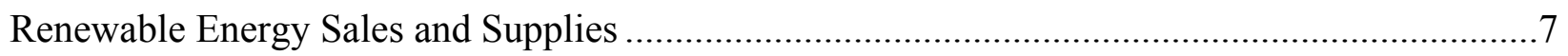

Green Power Sales and Revenues................................................................................

Ownership vs. Purchases of Supplies .........................................................................

New Renewable Capacity Installations ............................................................................

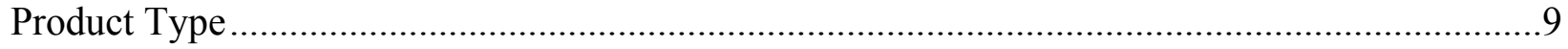

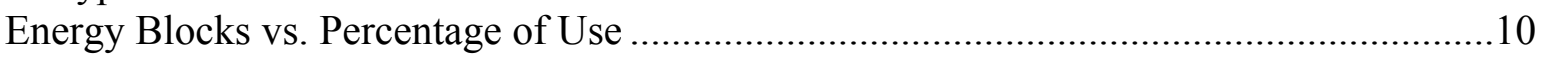

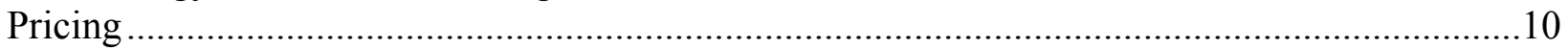

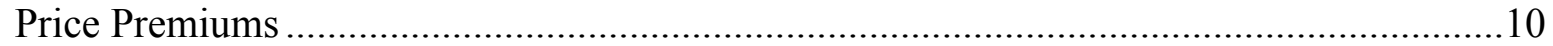

Protection from Fuel Costs and Environmental Charges....................................................12

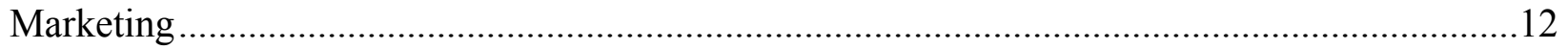

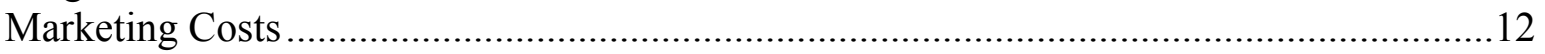

Cost Effectiveness of Marketing Techniques ...................................................................14

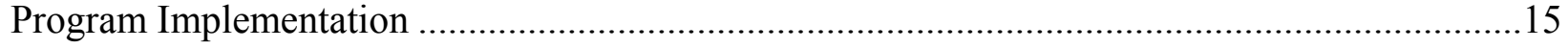

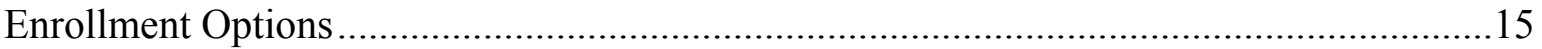

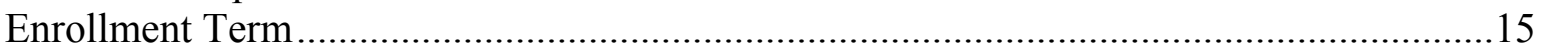

Program Evaluations and Market Research.......................................................................16

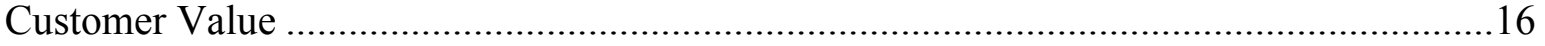

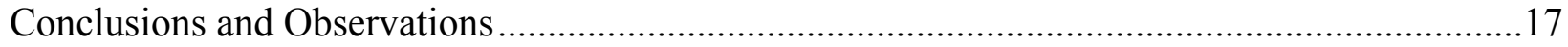

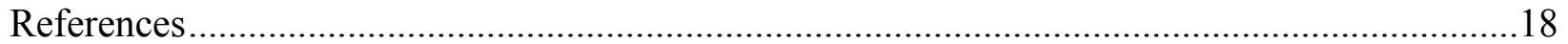

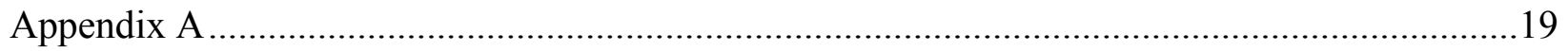

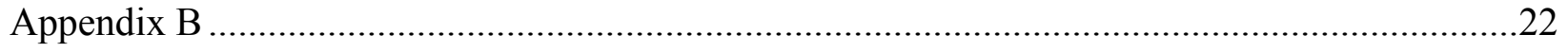

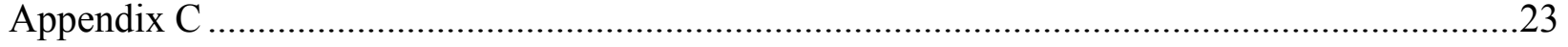




\section{List of Tables}

Table 1: Estimated Cumulative Number of Customers Participating in Utility Green Pricing Programs .

Table 2: Customer Participation Rates in Utility Green Pricing Programs, 1999-2002 ................5

Table 3: Average Participation Rate by Age of Green Pricing Programs, 2002 ........................6

Table 4: Green Pricing Participation Rates by Utility Type, 2002 .........................................6

Table 5: Annual Sales of Green Energy through Utility Green Pricing Programs ........................7

Table 6: Utility Procurement of Renewable Energy Supplies, 2002 ...........................................8

Table 7: New Renewables Capacity Supplying Green Pricing Programs, 2002 ........................9

Table 8: Price Premiums of Utility Green Power Products ........................................................11

Table 9: Green Pricing Premiums by Utility Type, 2002 ....................................................12

Table 10: Customer Acquisition Costs and Marketing Budgets, 2002 ....................................13

Table 11: Ranking the Cost-Effectiveness of Marketing Strategies ........................................14

Table 12: Methods of Enrolling in Green Pricing Programs ..................................................15

Table 13: Enrollment Term by Customer Segment .......................................................... 16

Table 14: Methods of Providing Additional Program Benefits ..............................................17

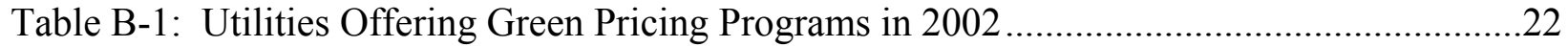

Table C-1: Green Pricing Program Renewable Energy Sales (as of December 2002)...............23

Table C-2: Total Number of Customer Participants (as of December 2002) ............................24

Table C-3: Customer Participation Rate (as of December 2002) ............................................25

Table C-4: Price Premium Charged for New, Customer-Driven Renewable Power....................26

\section{List of Figures}

Figure 1: Annual and Cumulative Renewable Energy Capacity Installations to Serve Green

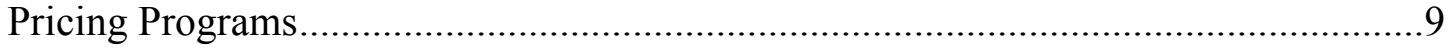

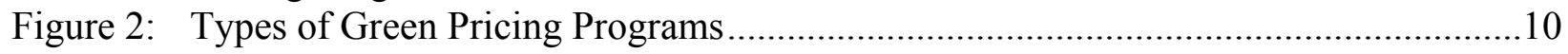

Figure 3: Utility Green Pricing Program Premiums .............................................................11

Figure 4: Utility-Reported Customer Acquisition Costs, 2002 ...........................................13 


\section{Executive Summary}

The term green pricing refers to programs offered by utilities in traditionally regulated electricity markets, which allow customers to support the development of renewable energy sources by paying a small premium on their electric bills. Since the introduction of the concept in the United States, the number of unique utility green pricing programs has expanded from just a few programs in 1993 to more than 90 in 2002. About $10 \%$ of U.S. utilities offered a green pricing option to about 26 million consumers by the end of 2002.

The purpose of this report is to provide: 1) aggregate industry data on consumer response to utility programs, which indicate the collective impact of green pricing on renewable energy development nationally; and 2) market data that can be used by utilities as a benchmark for gauging the relative success of their green pricing programs. Specifically, the paper presents current data and trends in consumer response to green pricing, as measured by renewable energy sales, participants, participation rates, and new renewable energy capacity supported. In addition, it presents data on various aspects of program design and implementation, such as product pricing, ownership of supplies, retention rates, marketing costs, the effectiveness of marketing techniques, and methods of enrolling and providing value to customers.

The following is a summary of key findings from our analysis.

\section{Consumer Response}

- Between 1999 and 2002, there was a fourfold increase in the number of customers participating in utility green pricing programs, with about 270,000 customers participating by the end of 2002 . Although the number of programs grew at a similar rate, 10 programs of the more than 90 offered are responsible for three-quarters of all customers.

- Sales of renewable energy through utility green pricing programs have grown on average about $40 \%$ annually during the past several years, driven primarily by the success of a relatively small number of programs - just three programs account for about half of all sales.

- While green power participants and sales have grown steadily over time, the average customer participation rate has remained largely steady at $1.2 \%$ to $1.3 \%$. The number of new programs introduced each year affects the average participation rate to some degree. Considering only those programs offered for three or more years, the average participation rate is just above $2 \%$. The most successful green pricing programs have achieved participation rates of between $3 \%$ and $6 \%$.

\section{Renewable Energy Supplies}

- The majority of utilities purchase a significant portion of the renewable energy used to supply their green power programs from third parties - only about one-quarter of utilities report directly owning all of the renewable generation sources. Utilities have shown increased interest in purchasing renewable energy certificates (RECs) to 
supply green pricing programs. At the end of 2002, utility REC purchases represented about $11 \%$ of all power sold through green pricing programs.

- More than 400 megawatts (MW) of new renewables capacity has been installed or planned as a result of utility green pricing programs. Installed capacity grew by $25 \%$ between 2001 and 2002. Wind, solar, and landfill gas are the renewable resources most commonly used for utility programs, with wind representing the largest portion of the total capacity.

\section{Pricing and Revenues}

- While the median price of renewable energy offered through green pricing programs has remained at 2.5 cents per kilowatt-hour $(\notin / \mathrm{kWh})$, the average price has declined by about $10 \%$ annually since 2000 . This reduction is driven in part by lower than expected costs for renewable energy supplies, financial incentives for new renewable energy development, and narrowing cost spreads between renewables and natural gas-fired generation.

- The majority of programs are structured to offer consumers the option of purchasing blocks of renewable energy, with $100 \mathrm{kWh}$ the most common block size.

- On average, customers spent about \$5 a month to purchase or support green power through utility programs during 2002.

- Utilities collected a total of about $\$ 15$ million in revenues from green power sales in 2002.

\section{Marketing}

- The median cost of acquiring new customers for green pricing programs was $\$ 35$, with an average of $\$ 43$. In addition, utilities spent (on average) about $20 \%$ of the total green power program budget on marketing, with a median of $15 \%$.

- Of the various marketing strategies utilized, bill inserts and earned media are rated highly cost-effective, followed by utility newsletters that featured articles about the green power program, direct-mail campaigns, and events. Although telemarketing is perceived by some utilities to be the most cost-effective strategy, it is not commonly used.

\section{Program Implementation}

- Green pricing programs exhibit high customer-retention rates, generally 95\% annually or better.

- The most common methods of adding value for green pricing participants are program updates in periodic newsletters and window decals. In addition, many programs recognize business customer participation through program advertisements or in local media, or provide customers with plaques or other recognition.

- The most commonly used methods to enroll customers in green pricing programs are through the utility's call center, via mail-in cards, during special events, and to a lesser extent, via the utility's Web site. Fewer than $10 \%$ of utilities allow customers to enroll by checking a box on their utility bill. 


\section{Introduction}

The term green pricing refers to programs offered by utilities in traditionally regulated electricity markets, which allow customers to support the development of renewable energy sources by paying a small premium on their electric bills.

Since the introduction of the concept in the United States, the number of unique utility green pricing programs has expanded from just a few programs in 1993 to more than 90 in 2002. Because some of these programs are marketed by cooperative associations or public power entities that serve multiple distribution utilities, collectively more than 300 investor-owned and consumer-owned utilities in 32 states offered green pricing by the end of 2002. Thus, about $10 \%$ of U.S. utilities offered a green pricing option to about 26 million consumers.

Initially, utilities offered green pricing to prepare for competition and to gain experience with renewable energy technologies. More recently, growth has been fueled in part by state laws requiring utilities to offer green power options and the improved economics of renewable energy technologies (Bird and Swezey 2003a). Despite the shift in motivation, utility green power options have increased steadily - since 1998, the number of green pricing programs has grown at an annual average rate exceeding $40 \%$.

The magnitude of support that green pricing provides for renewable energy development depends not only on access to these programs, but also on consumer interest and participation. Studies have found that green pricing programs have had varying success in garnering customers and in supporting renewable energy development (Lieberman 2002; Swezey and Bird 2001; Wiser et al. 2000). For example, in 2001, more than half of all programs experienced participation rates below $1 \%$ and just four programs were responsible for more than half of the renewable energy capacity installed to serve green pricing customers (Swezey and Bird 2001).

The purpose of this paper is to provide: 1) aggregate industry data on consumer response to utility programs, which indicates the collective impact of green pricing on renewable energy development nationally; and 2) market data that can be used by utilities as a benchmark for gauging the relative success of their green pricing programs. Specifically, the paper presents current data and trends in consumer response to green pricing, as measured by renewable energy sales, participants, participation rates, and new renewable energy capacity supported. In addition, it presents data on various aspects of program design and implementation, such as product pricing, ownership of supplies, retention rates, marketing costs, the effectiveness of marketing techniques, and methods of enrolling and providing value to customers.

A companion piece (Wiser et al. 2004) reports the results of a detailed statistical analysis of this data to provide insights into what specific program features might help maximize the effectiveness of utility green pricing programs. 


\section{Data Collection and Methodology}

The information presented in this report is based on data collected by the National Renewable Energy Laboratory (NREL). Since 1999, NREL has collected information on green pricing program participants, participation rates, retention rates, price premiums, green energy sales, new renewables capacity installed to supply green pricing programs, and enrollment requirements (Bird and Swezey 2003a, Swezey and Bird 2000, Swezey and Bird 1999). Prior to 2002, information was collected by telephone. For 2002, a questionnaire was prepared, which included questions on marketing and program implementation that went beyond the data solicited in previous years.

The 2002 questionnaire was distributed via e-mail to 82 green pricing program managers representing 90 green pricing programs (see Appendix $\mathbf{A}$ for the questionnaire and Appendix B for a list of utilities that offer green pricing programs). Utilities were asked to complete a separate questionnaire for each green pricing program offered. For programs administered through a generation and transmission cooperative or a public power supplier, the questionnaire was typically sent only to the power supplier, rather than to the participating distribution utilities. However, in some cases, the power supplier was not able to provide data on marketing and program implementation. Therefore, the authors did obtain data from a small number of municipal utilities and cooperatives that participate in jointly marketed programs for which contact information was available. Four programs were found to be inactive, thus reducing the total number of programs to 86. Responses were received for a total of 66 programs, yielding an overall program response rate of $77 \%{ }^{1}$

\section{Customer Participation}

\section{Number of Customers}

At the end of 2002, an estimated 270,000 customers were participating in utility green pricing programs nationally, including about 3,900 nonresidential customers. The top 10 programs accounted for about three-quarters of all participants (see Appendix C). Between 1999 and 2002, the number of customers participating in utility green pricing programs increased four-fold. During 2002, the total number of customers increased by $27 \%$.

Table 1 delineates residential and nonresidential customer participation over time. During 2002, the number of nonresidential customers participating in green pricing programs increased by $54 \%$ - twice the rate of growth of participation among residential customers. This may be explained, in part, by an increased emphasis on marketing to the commercial and industrial sector in recent years, while many early green pricing programs primarily targeted residential customers.

\footnotetext{
${ }^{1}$ Where possible, data gaps were filled with information obtained from other sources, including audits of utility green pricing programs, utility Web sites, and published reports (Harris 2002; Washington CTED and UTC 2002), as well as with data collected by NREL in previous years.
} 
Table 1: Estimated Cumulative Number of Customers Participating in Utility Green Pricing Programs

\begin{tabular}{|c|c|c|c|c|}
\hline Customer Segment & 1999 & 2000 & 2001 & 2002 \\
\hline Residential & $\mathrm{N} / \mathrm{a}^{*}$ & 163,520 & 209,820 & 266,637 \\
\hline Nonresidential & $\mathrm{N} / \mathrm{a}^{*}$ & 1,680 & 2,520 & 3,890 \\
\hline Total & 66,930 & 165,200 & 212,340 & 270,527 \\
\hline \multicolumn{5}{|c|}{$\begin{array}{l}\text { *Information on customer segments was not collected in } 1999 . \\
\text { Note: This data includes estimates for programs beyond those represented in the } \\
\text { questionnaire responses. Supplemental data was obtained from a variety of sources, } \\
\text { including audits of utility green pricing programs, utility Web sites, published reports } \\
\text { (Harris 2002; Washington CTED and UTC 2002), and previous NREL data collection } \\
\text { efforts. }\end{array}$} \\
\hline
\end{tabular}

\section{Participation Rates}

At the end of 2002, the average rate of participation in green pricing programs among eligible utility customers was $1.3 \%$, with a median of $0.9 \%$ (see Table 2). The most successful programs achieved participation rates of between $3 \%$ and $5.8 \%$ (see also Appendix C). ${ }^{2}$ Between 1999 and 2002, average participation rates for green pricing programs increased only slightly. This lack of improvement can be attributed partly to the introduction of new programs over time. For example, more than 20 new green pricing programs were introduced in 2002 alone. $^{3}$

Table 2: Customer Participation Rates in Utility Green Pricing Programs, 1999-2002

\begin{tabular}{|c|c|c|c|c|}
\hline Participation Rate & 1999 & 2000 & 2001 & 2002 \\
\hline Average & $0.9 \%$ & $1.2 \%$ & $1.3 \%$ & $1.3 \%$ \\
\hline Median & $0.8 \%$ & $0.7 \%$ & $0.7 \%$ & $0.9 \%$ \\
\hline Top 10 programs & $2.1 \%-4.7 \%$ * & $2.6 \%-7.3 \%$ & $3.0 \%-7.0 \%$ & $3.0 \%-5.8 \%$ \\
\hline
\end{tabular}

For those programs that have been offered for one or more years, data show increasing rates of participation (see Table 3). At the end of 2002, the average participation rate for programs that were at least three years old was $2.2 \%$, compared to $1.3 \%$ for all programs. Wiser et al. (2004) found a positive and statistically significant relationship between participation rates and program duration. They also found that program design, implementation, and marketing play a role in influencing participation rates. Thus, it can

\footnotetext{
${ }^{2}$ The high end of the range declined from 2000 to 2002 because the utility with the highest participation rate (Moorhead Public Service) has experienced an increase in its overall customer base while the number of participants in its green pricing program has remained steady. The program was fully subscribed in 2000 and the utility has not attempted to expand it.

${ }^{3}$ Many of these programs were introduced in Washington to satisfy a state law requiring utilities to offer green power options.
} 
be postulated that participation rates grow over time as customers become increasingly aware of green product offerings and utilities become more adept at product marketing.

Table 3: Average Participation Rate by Age of Green Pricing Programs, 2002

\begin{tabular}{|l|l|}
\hline All programs & $1.3 \%$ \\
\hline Programs at least 1 year old & $1.6 \%$ \\
\hline Programs at least 2 years old & $1.6 \%$ \\
\hline Programs at least 3 years old & $2.2 \%$ \\
\hline Programs at least 4 years old & $2.1 \%$ \\
\hline
\end{tabular}

Table 4 shows that across all utilities the average participation rate in 2002 for residential customers was $1.4 \%$ and $0.9 \%$ for nonresidential customers. The median participation rate for residential customers was $1.0 \%$ but only $0.1 \%$ for nonresidential customers. The lower participation rates among nonresidential customers may be explained, in part, by the fact that programs have historically placed less emphasis on the nonresidential sector.

Table 4 also shows that differences exist in average participation rates among programs offered by investor-owned utilities (IOUs), municipal or public utilities, and cooperatives; however, these differences are narrowed when one compares the median rates. Of the three, cooperative utilities reported higher average participation rates, particularly for nonresidential customers. ${ }^{4}$ Average participation rates were lowest among IOUs. However, caution is advised in drawing conclusions based on these data. For example, after performing a statistical analysis of the same data set, Wiser et al. (2004) found no evidence that the type of utility ownership influences participation rates but did find that smaller utilities tend to achieve higher participation rates.

Table 4: Green Pricing Participation Rates by Utility Type, 2002

\begin{tabular}{|l|c|c|c|c|}
\hline Utility Type & $\begin{array}{c}\text { Number of } \\
\text { Programs }\end{array}$ & $\begin{array}{c}\text { Residential } \\
\text { Customers } \\
\text { Average/Median }\end{array}$ & $\begin{array}{c}\text { Nonresidential } \\
\text { Customers } \\
\text { Average/Median }\end{array}$ & $\begin{array}{c}\text { All Customers } \\
\text { Average/Median }\end{array}$ \\
\hline All Utilities & 66 & $1.4 \% / 1.0 \%$ & $0.9 \% / 0.1 \%$ & $1.3 \% / 0.9 \%$ \\
\hline Cooperatives & 11 & $2.2 \% / 1.1 \%$ & $5.5 \% / 0.5 \%$ & $2.0 \% / 0.9 \%$ \\
\hline Public & 33 & $1.4 \% / 1.1 \%$ & $0.3 \% / 0.1 \%$ & $1.3 \% / 1.0 \%$ \\
\hline Investor-owned & 22 & $1.1 \% / 0.8 \%$ & $0.2 \% / 0.1 \%$ & $1.0 \% / 0.8 \%$ \\
\hline
\end{tabular}

\footnotetext{
${ }^{4}$ Because the number of responses from cooperative utilities was limited, these averages may not be representative of all cooperative programs. For example, one cooperative reported a $30 \%$ participation rate among nonresidential customers, which dramatically raised the average for all cooperative programs. This also partially explains the large difference between average and median participation rates for nonresidential customers among all utility programs noted previously.
} 


\section{Retention of Customers}

In 2002, utilities reported that an average of $4.3 \%$ and a median of $2.5 \%$ of customers dropped out of green pricing programs. Thus, the annual retention rate among programs was generally $95 \%$ or better. Historically, utilities that have reported higher-than-average turnover rates among green power customers cite high turnover among all utility customers; for example, several of these utilities have service territories that include large universities where customer turnover is recurrent. And a few utilities have experienced higher than average decreases in enrollment as a result of general rate increases. However, other utilities have reported steady enrollments in green power programs despite rate increases.

\section{Renewable Energy Sales and Supplies}

\section{Green Power Sales and Revenues}

Collectively, utilities sold 895 million kilowatt-hours (kWh), or 102 average megawatts (aMW), of green power to customers in 2002 (see Table 5). Green power sales to all customer classes grew by $58 \%$ in 2002 , compared to $25 \%$ in 2001 . The 10 topperforming green pricing programs represented more than $80 \%$ of total sales (see Appendix C). Nonresidential customers accounted for about one-quarter of all purchases in 2002.

On average, residential customers spent $\$ 4.83$ a month to purchase or support green power through utility programs. We calculate that utilities collected about $\$ 15$ million in revenues from green power sales in 2002. Green pricing program revenues are typically used to pay the above-market costs of renewables as well as the costs of administering and marketing the program - although the treatment of the latter differs by utility (see Holt and Holt 2004; Swezey and Bird 2001).

Table 5: Annual Sales of Green Energy through Utility Green Pricing Programs (millions of kWh)

\begin{tabular}{|l|c|c|c|}
\hline & $\mathbf{2 0 0 0}$ & $\mathbf{2 0 0 1}$ & $\mathbf{2 0 0 2}$ \\
\hline Residential customers & --- & 332.7 & 661.3 \\
\hline Nonresidential customers & --- & 164.4 & 233.7 \\
\hline All customers & 453.7 & 568.0 & 895.0 \\
\hline \% Nonresidential & --- & $29 \%$ & $26 \%$ \\
\hline "Sales information for customer segments not available for 2000. \\
\hline
\end{tabular}

\section{Ownership vs. Purchases of Supplies}

About one-quarter of utilities supply their green pricing programs entirely from their own renewable energy generation facilities (see Table 6). Another $46 \%$ of utilities either 
purchase all of their power from an independent power generator or purchase renewable energy certificates (RECs) from a marketer or supplier. ${ }^{5}$ The remaining utilities use a combination of these approaches to supply their green power programs. Collectively, utilities purchased 102.6 million $\mathrm{kWh}$ of RECs to serve green power customers in 2002, which represents about $11 \%$ of all green power sold through utility green pricing programs. The use of RECs to supply utility green pricing programs is a relatively recent development; prior to 2001, very few utilities purchased unbundled RECs. Most utilities that supply their programs with RECs are in the Pacific Northwest.

Table 6: Utility Procurement of Renewable Energy Supplies, 2002

\begin{tabular}{|l|c|c|c|c|c|c|}
\hline & \multicolumn{2}{|c|}{$\begin{array}{c}\text { Utilities that } \\
\text { Own } \\
\text { Generation }\end{array}$} & \multicolumn{2}{|c|}{$\begin{array}{c}\text { Utilities that } \\
\text { Purchase } \\
\text { Power }\end{array}$} & $\begin{array}{c}\text { Utilities that } \\
\text { Purchase } \\
\text { RECs }\end{array}$ \\
\hline $\begin{array}{l}\text { For } 100 \% \text { of program power } \\
\text { supplies }\end{array}$ & 16 & $24 \%$ & 23 & $35 \%$ & 7 & $11 \%$ \\
\hline $\begin{array}{l}\text { For at least 50\% of program power } \\
\text { supplies }\end{array}$ & 20 & $30 \%$ & 29 & $44 \%$ & 7 & $11 \%$ \\
\hline $\begin{array}{l}\text { For any fraction of program power } \\
\text { supplies }\end{array}$ & 25 & $38 \%$ & 30 & $45 \%$ & 10 & $15 \%$ \\
\hline Note: Percentages based on 60 respondents.
\end{tabular}

\section{New Renewable Capacity Installations}

The amount of renewable energy capacity installed to serve green pricing programs has grown dramatically over the last several years (see Figure 1). ${ }^{6}$ At the end of 2002, utilities had installed nearly $290 \mathrm{MW}$ of renewables capacity with another $140 \mathrm{MW}$ planned (see Table 7). In addition, some utilities purchase power or RECs from wholesale marketers that are not included in these estimates. Wind, solar, and landfill gas are the renewable resources most commonly included in green pricing programs, with wind representing the largest portion of the total capacity - at the end of 2002, wind energy represented nearly $80 \%$ of the installed capacity.

While many programs use blends of renewable energy sources, some programs feature only one energy source. Among the programs offered, 32 programs use only wind, 10 use only solar, and seven use only biomass. The remaining programs offer a blend of two or more resources.

\footnotetext{
${ }^{5}$ RECs represent the environmental attributes of renewable energy-generating facilities and can be sold separately from commodity electricity.

${ }^{6}$ The timing of capacity installations in the more recent years has been influenced by the availability of the federal production tax credit (PTC) for wind energy facilities. As with wind energy installations generally, more capacity has been installed in years when the PTC was scheduled to expire (1999 and 2001) as developers have rushed to complete projects. Development has lagged in the interim years because of the uncertainty surrounding the PTC extension and the lead times necessary to plan and complete projects. This explains the relatively small amount of capacity installed in 2000 and 2002, compared to capacity additions in 2001 and those planned for 2003.
} 


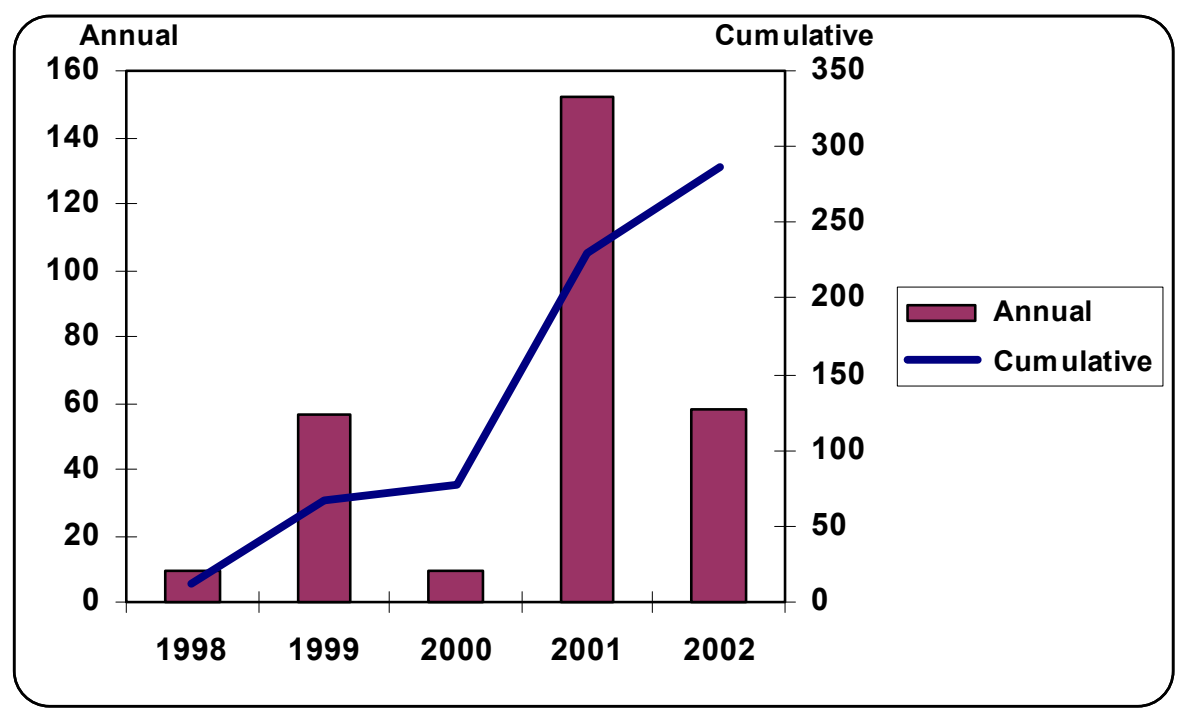

Figure 1: Annual and Cumulative Renewable Energy Capacity Installations to Serve Green Pricing Programs (Megawatts)

Table 7: New Renewables Capacity Supplying Green Pricing Programs, 2002 (Megawatts)

\begin{tabular}{|l|r|r|r|r|}
\hline Source & \multicolumn{2}{|c|}{ Installed } & \multicolumn{2}{c|}{ Planned } \\
\hline Wind & 225.6 & $78.5 \%$ & 111.3 & $80.3 \%$ \\
\hline Biomass & 43.5 & $15.1 \%$ & 23.9 & $17.2 \%$ \\
\hline Solar & 4.2 & $1.4 \%$ & 1.4 & $1.0 \%$ \\
\hline Geothermal & 5.5 & $1.9 \%$ & 0.0 & $0.0 \%$ \\
\hline Small Hydro & 8.6 & $3.0 \%$ & 2.0 & $1.4 \%$ \\
\hline Total & 287.3 & $100.0 \%$ & 138.5 & $100.0 \%$ \\
\hline Source: Bird and Swezey 2003b \\
\hline
\end{tabular}

\section{Product Type}

Most utility green pricing programs are structured so that customers can purchase renewable energy to meet some or all of their electricity needs. The green power premium charged in these "energy-based" programs is typically expressed in $\phi / \mathrm{kWh}$ or $\$ / \mathrm{kWh}$ block. Other programs are structured to allow customers to contribute funds that are used to support the development of renewable energy sources. These so-called "contribution programs" have become less common over time and currently represent only $15 \%$ of all programs (see Figure 2). Finally, a few utilities have offered programs through which customers make a monthly payment tied to the amount of renewable energy capacity that is supported ("capacity-based programs"). For example, customers might be offered the option to pay $\$ 6$ each month to support 100 watts of solar energy 
development. Capacity-based programs are no longer actively marketed and, in some cases, are being phased out in favor of energy-based programs.

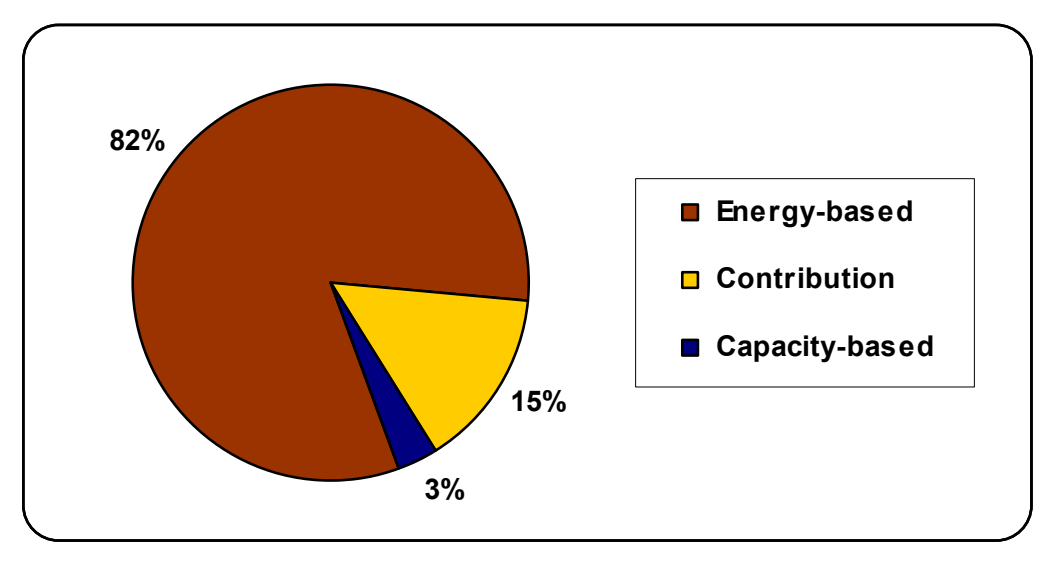

Figure 2: Types of Green Pricing Programs

\section{Energy Blocks vs. Percentage of Use}

About two-thirds of energy-based programs are structured so that customers can purchase blocks of green power. Block sizes range from $15 \mathrm{kWh}$ for energy derived exclusively from solar systems to $1,000 \mathrm{kWh}$ for energy derived from a blend of new wind sources and existing renewables. The most common block size offered to residential customers is $100 \mathrm{kWh}$, with an average size of $125 \mathrm{kWh}$. Many utilities offer larger block sizes to nonresidential customers and some offer customers the option of purchasing green power for all of the electricity they use.

The remaining programs allow customers to purchase green power for some fraction of their electricity needs. Most of these programs allow residential customers to elect to have $25 \%, 50 \%$, or $100 \%$ of their electricity come from renewable sources, while a few offer fractions as small as $10 \%$. Often, commercial and industrial customers are able to purchase green power for a smaller fraction of their electricity use.

\section{Pricing}

\section{Price Premiums}

In 2002, price premiums for energy-based programs ranged from $0.7 \phi / \mathrm{kWh}$ to $17.6 \phi / \mathrm{kWh}$, with an average premium of $2.82 \phi / \mathrm{kWh}$ and a median of $2.50 \phi / \mathrm{kWh}$. Figure 3 displays price premiums for individual utility programs - solar-only products dominate the high end of the price range. Since 2000, the average price premium has dropped at an average rate of about $10 \%$ annually although the median premium has remained constant (see Table 8). Some of this reduction can be attributed to lower than expected costs for renewable energy supplies and the availability of state or federal financial incentives. In 
addition, increases in the cost of natural gas have reduced the cost spread between renewable energy and gas-fired generation.

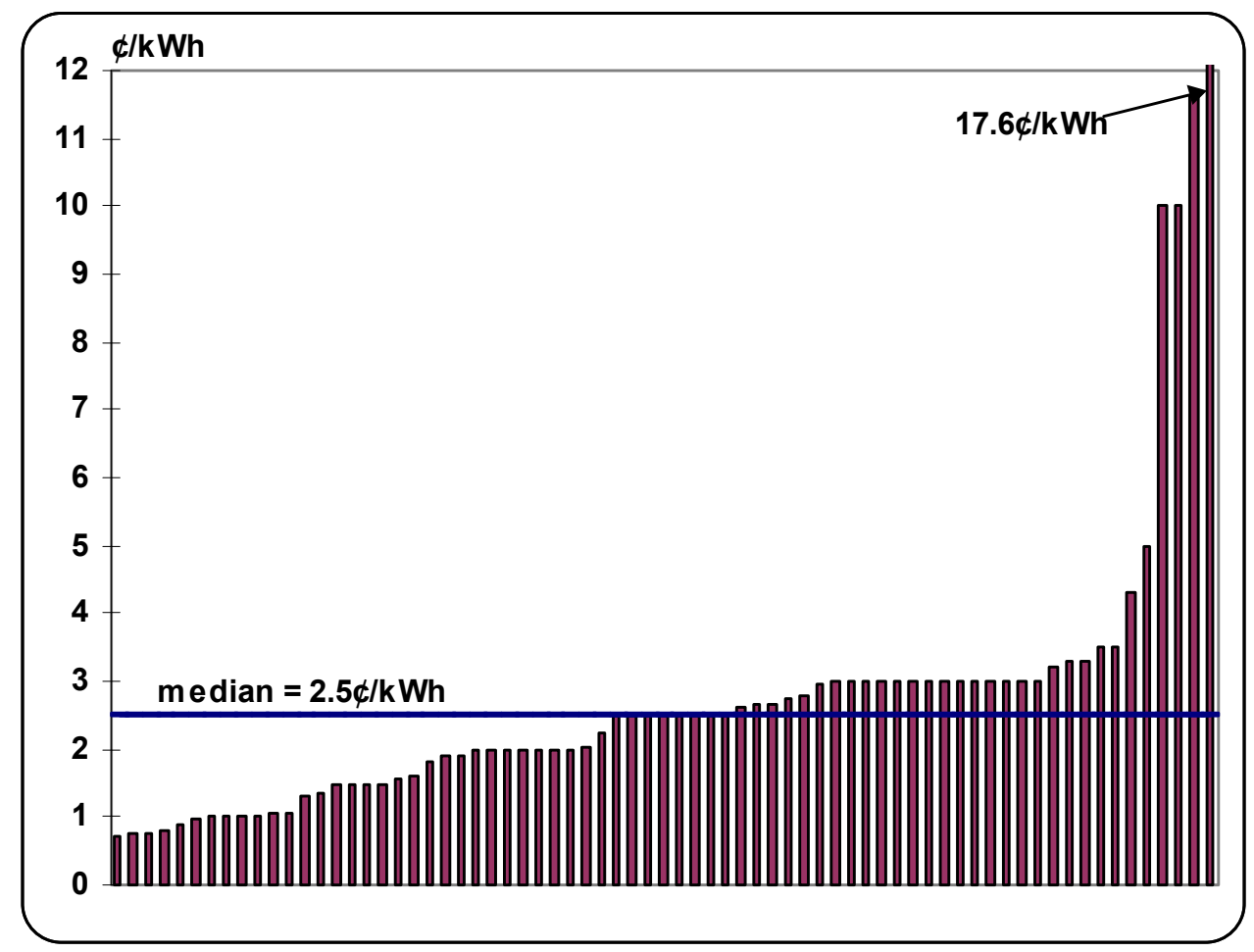

Figure 3: Utility Green Pricing Program Premiums (Energy-Based Programs Only)

Table 8: Price Premiums of Utility Green Power Products $(\phi / k W h)$

\begin{tabular}{|l|c|c|c|c|}
\hline & $\mathbf{1 9 9 9}$ & $\mathbf{2 0 0 0}$ & $\mathbf{2 0 0 1}$ & $\mathbf{2 0 0 2}$ \\
\hline Average Premium & 2.15 & 3.48 & 2.93 & 2.82 \\
\hline Median Premium & 2.00 & 2.50 & 2.50 & 2.50 \\
\hline Range of Premiums & $0.5-5.0$ & $(0.5)-20.0$ & $0.9-17.6$ & $0.7-17.6$ \\
\hline 10 Programs with Lowest Premiums ${ }^{*}$ & $0.4-2.5^{* *}$ & $(0.5)-2.5$ & $1.0-1.5$ & $0.7-1.5$ \\
\hline Number of Programs Represented & 24 & 50 & 60 & 80 \\
\hline $\begin{array}{l}\text { *Represents the 10 utility programs with the lowest price premiums for new customer-driven renewable energy. } \\
\text { This includes only programs that have installed - or announced firm plans to install or purchase power from - } \\
\text { new renewable energy sources. } \\
\text { ** Data for April 2000. }\end{array}$ \\
\hline
\end{tabular}

Table 9 presents green pricing premiums by type of utility. Investor-owned utilities have the highest average price premium $(3.5 \varnothing / \mathrm{kWh})$ while public and cooperative utilities have lower average premiums $(2.5 \mathrm{c} / \mathrm{kWh})$. Public utilities have the lowest median premium $(2.0 \notin / \mathrm{kWh})$. Some of the difference among utility types may result from a greater 
tendency of IOUs to include program administration and marketing costs in the premium or to seek recovery of program costs over a shorter period of time. The higher average premium calculated for investor-owned utilities may also stem from the fact that several IOUs offer solar-only programs with relatively high premiums, on the order of $10 \notin / \mathrm{kWh}$ or higher.

Table 9: Green Pricing Premiums by Utility Type, 2002 $(\phi / k W h)$

\begin{tabular}{|l|c|c|c|}
\hline Type of Utility & Average & Median & Range \\
\hline Investor-owned & 3.54 & 2.5 & $0.78-17.6$ \\
\hline Public & 2.51 & 2.0 & $0.70-11.6$ \\
\hline Cooperative & 2.48 & 2.5 & $1.0-3.5$ \\
\hline All Utilities & 2.82 & 2.5 & $0.70-17.6$ \\
\hline
\end{tabular}

\section{Protection from Fuel Costs and Environmental Charges}

Because most renewable energy facilities do not rely on fuel, some utilities offer fixedprice green power products or exempt their green power customers from fuel-cost charges. Seven utilities operating programs in 2002 included this feature as a component of their green pricing product. ${ }^{7}$ One of these utilities also exempts green power customers from the costs associated with making environmental improvements at its fossil-fuel generating facilities.

\section{Marketing}

\section{Marketing Costs}

One measure of the cost of marketing a green pricing program is customer-acquisition cost - the amount spent on marketing, divided by the number of new customers that enroll in the program. Utilities reported a median customer-acquisition cost for green pricing programs of $\$ 35$, with an average of $\$ 43$ (see Table 10). ${ }^{8}$ However, the responses varied widely, ranging from $\$ 1$ to $\$ 200$ (see Figure 4). And customer-acquisition costs can vary over time.

Another indication of the cost and level of effort devoted to marketing is the fraction of the total program budget spent on marketing. ${ }^{9}$ Utilities reported that, on average, about

\footnotetext{
${ }^{7}$ The seven utilities offering fuel-price stability were: Alliant Energy, Austin Energy, Eugene Water \& Electric Board, Madison Gas and Electric, Otter Tail Power, We Energies, and Xcel Energy (Colorado program only).

${ }^{8}$ Only about half of the utilities provided this information. This relative lack of responses may be due in part to the fact that many utilities do not track customer acquisition costs.

${ }_{9}^{9}$ Program costs typically include the above-market costs of acquiring the renewable energy resources, marketing, and program administration.
} 
$20 \%$ of the total green power program budget was spent on marketing, with a median of 15\% (see Table 10). ${ }^{10}$

Table 10: Customer Acquisition Costs and Marketing Budgets, 2002

\begin{tabular}{|l|c|c|c|}
\hline & Average & Median & Responses \\
\hline Customer acquisition costs & $\$ 43$ & $\$ 35$ & 28 \\
\hline Marketing component of total program budget & $19.6 \%$ & $14.5 \%$ & 29 \\
\hline
\end{tabular}

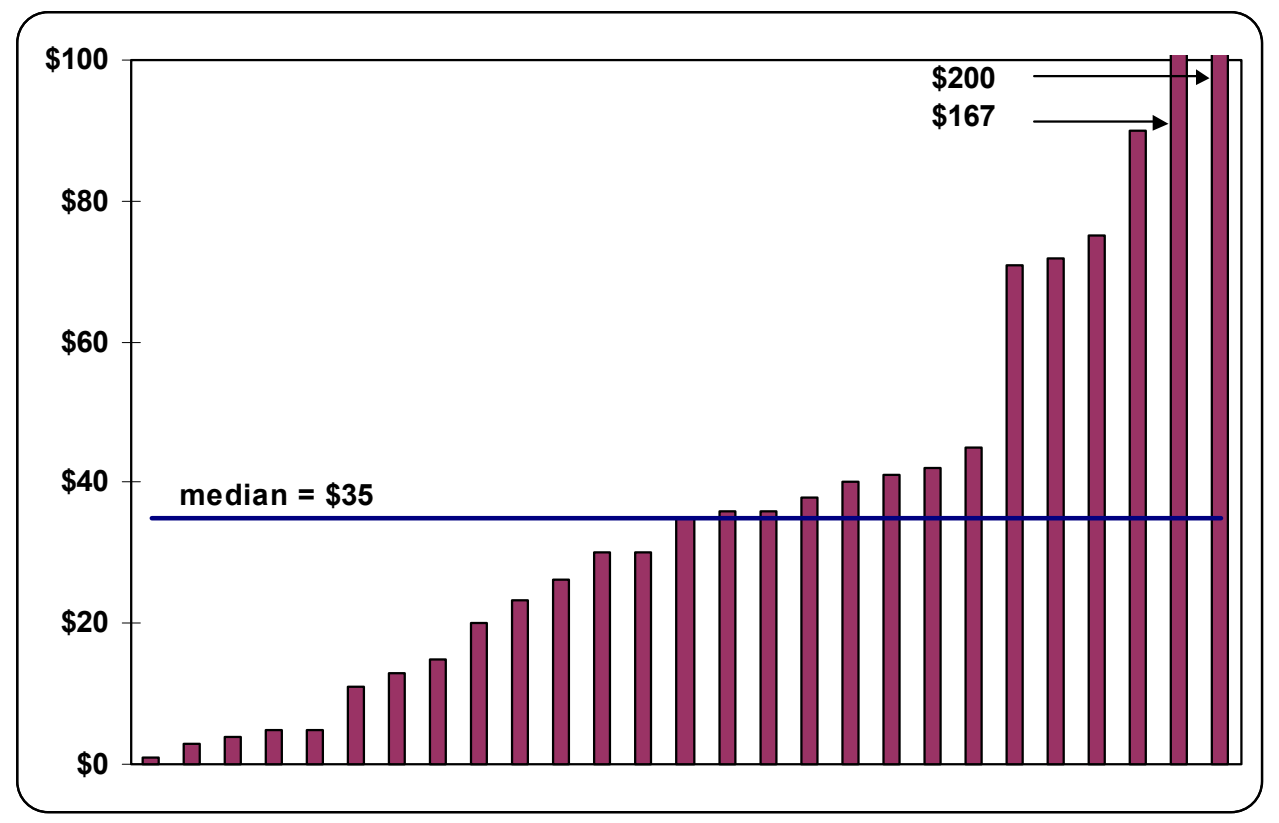

Figure 4: Utility-Reported Customer Acquisition Costs, 2002

Utilities were not specifically asked to report the size of the marketing budget. However, some utilities have publicly reported this information. For example, an investor-owned utility with 700,000 customers that teams with a competitive marketer to promote three separate green power product offerings reported a total marketing budget of $\$ 1,100,000$ in 2002, while a municipal utility of 500,000 customers reported a marketing budget of $\$ 200,000$ annually (Harris 2002). A mid-sized municipal utility, which serves about 80,000 customers, reported a marketing budget of about $\$ 35,000$ per year; while a small electric cooperative, with about 12,000 members, reported a marketing budget of about

\footnotetext{
${ }^{10}$ Again, only about half of the utilities responding provided this information. Also, the responses to this question varied considerably, suggesting that utilities may have interpreted it differently. Some utilities may have reported the percentage of all program revenues spent on marketing, while others may have reported the fraction of program implementation budgets devoted to marketing. Given that the intention was to collect information on the former, responses indicating that $100 \%$ of the budget was spent on marketing were omitted.
} 
$\$ 3,000$ annually (Harris 2002). Another small municipal utility (12,000 customers) reported that the utility's entire marketing budget had been used to promote its green pricing program. The program manager reported that the utility received more positive publicity and recognition within the community from promoting its green pricing program than from any previous marketing activities. ${ }^{11}$

\section{Cost Effectiveness of Marketing Techniques}

Utility green pricing program managers were asked to rank the cost-effectiveness of various marketing techniques used in 2002 (see Table 11). Although telemarketing was rated highly, it was not commonly used - only five utilities reported using telemarketing. Bill inserts and publicity (e.g., newspaper articles or other local press) were also highly rated and were used more frequently. Also commonly used, but ranked below bill inserts and publicity in cost-effectiveness, were utility newsletters that featured articles about the green power program. In some cases, particularly for smaller utilities, newsletters are the primary method of communicating with customers. Direct mail, which can be used to target a select group of utility customers, received a middle rating (3 out of 5) in terms of cost-effectiveness. Several utilities reported using direct mail specifically to target small commercial and industrial customers. Other marketing strategies reported by utilities but not listed in the questionnaire were: Web site/online ads (reported by 6 utilities), public presentations (2), magazine articles (1), door hangers (1), school essay contest (1), oneon-one visits (1), and call center (1). ${ }^{12}$

Table 11: Ranking the Cost-Effectiveness of Marketing Strategies

\begin{tabular}{|l|c|c|}
\hline Marketing Technique & Rating $^{*}$ & Responses \\
\hline Telemarketing & 5.0 & 5 \\
\hline Bill inserts & 4.2 & 39 \\
\hline Publicity & 4.0 & 38 \\
\hline Utility newsletter & 3.3 & 42 \\
\hline Direct mail & 3.1 & 33 \\
\hline Other & 3.1 & 19 \\
\hline Events & 2.7 & 48 \\
\hline Television ads & 2.2 & 12 \\
\hline Radio ads & 2.2 & 22 \\
\hline Newspaper ads & 2.1 & 26 \\
\hline Billboards & 2.0 & 4 \\
\hline *Respondents were asked to rank the cost-effectiveness of the marketing \\
strategies listed on a scale from 1 to 5, with 5 being the most cost-effective.
\end{tabular}

\footnotetext{
${ }^{11}$ Presentation by Chris Reed, Moorhead Public Service, to the Green Pricing Workshop, St. Paul, MN, October 24, 2001.

${ }^{12}$ Lieberman 2002 reviewed marketing data for public utilities with similar findings except that direct mail was ranked higher and events lower.
} 


\section{Program Implementation}

\section{Enrollment Options}

Utilities reported that the most common methods of enrolling customers in green pricing programs were: over the phone through the utility's call center, via mail-in cards, and during special events. Enrollment via the utility's Web site was also common with about three-quarters of the programs offering this option. Less than $10 \%$ of utilities allowed customers to enroll by checking a box on their utility bills. Other methods listed included newspaper advertisements and Web-based forms that could be mailed to the utility. On average, utilities offered four of the six enrollment options listed in the questionnaire (see Table 12).

Table 12: Methods of Enrolling in Green Pricing Programs

\begin{tabular}{|l|c|c|}
\hline & $\begin{array}{c}\text { Positive } \\
\text { Responses }\end{array}$ & \\
\hline Phone (through utility call center) & 58 & $91.9 \%$ \\
\hline Sign up at special events & 57 & $90.3 \%$ \\
\hline Returning mail-in card & 57 & $90.3 \%$ \\
\hline Utility Web site & 46 & $74.2 \%$ \\
\hline Other & 14 & $22.6 \%$ \\
\hline Check-box on utility bill & 5 & $8.2 \%$ \\
\hline $\begin{array}{l}\text { Note: The number of respondents was 62 for all methods except for check- } \\
\text { box (61). }\end{array}$ \\
\hline
\end{tabular}

\section{Enrollment Term}

About one-third of utilities require residential customers to subscribe to green pricing programs for a minimum period of time while $40 \%$ have an enrollment term requirement for nonresidential customers (see Table 13). One year is the most common minimum enrollment period with requirements ranging from zero to 10 years. In some cases, utilities require nonresidential customers to sign up for longer periods of time than residential customers. Among all utilities, less than 10\% require enrollment terms of more than one year for residential customers, while about $14 \%$ require nonresidential enrollment beyond one year. Despite the existence of these contract requirements, some utilities have reported that they are not enforced. 
Table 13: Enrollment Term by Customer Segment

\begin{tabular}{|l|c|c|}
\hline & Residential & Nonresidential \\
\hline Percent of utilities with a minimum enrollment term & $33 \%$ & $40 \%$ \\
\hline Most common enrollment term & 1 year & 1 year \\
\hline Range of contract terms & $0-10$ years & $0-10$ years \\
\hline
\end{tabular}

\section{Program Evaluations and Market Research}

Nearly two-thirds (64\%) of utilities reported that they had conducted customer research to aid in the design of their green pricing program or to develop a marketing plan. In addition, $44 \%$ of utilities indicated that they had conducted an evaluation of their green pricing program. However, the questionnaire did not ask whether the research or evaluation was conducted specifically in 2002 - some utilities may have performed customer research or evaluations in previous years, but not reported it because the majority of the questions pertained to 2002. Therefore, there may be a downward bias in these responses.

\section{Customer Value}

Response to utility green pricing programs can be influenced by additional values offered to customers. For example, customers may be more willing to participate in a program if their participation is recognized or rewarded, or if they receive other products and services, such as compact fluorescent light bulbs or store discounts. Wiser et al. 2004 found evidence that providing additional values increases green power purchase rates among nonresidential customers.

Table 14 indicates the number and percentage of utilities that provide additional benefits to customers, based on a list of options included in the 2002 questionnaire. Of the 11 options listed, respondents indicated that their utilities offered an average of three additional benefits to their green pricing customers. The most common methods were 1) to inform customers about the status of the program through newsletters that provide periodic program updates, and 2) to provide decals that can be displayed in windows. Other types of customer recognition were also common. For example, $45 \%$ of utilities reported that they recognized business-customer participation in program advertisements or local media, while $41 \%$ reported that they provided customers with plaques or other items. About one-third of utilities provided customers with tours of renewable energy projects or worked with local schools to develop renewable energy educational programs or install renewable energy systems on school buildings. Nearly one-quarter of utilities indicated that they provided customers with compact fluorescent light bulbs or other energy efficiency products. ${ }^{13}$

\footnotetext{
${ }^{13}$ This may be an overestimate because some utilities may have indicated that they offer energy efficiency products or services, even if they are not directly associated with the green power programs.
} 
Table 14: Methods of Providing Additional Program Benefits

\begin{tabular}{|l|c|c|c|}
\hline & $\begin{array}{c}\text { Positive } \\
\text { Responses }\end{array}$ & Respondents & $\%$ \\
\hline Newsletters that provide program updates & 39 & 61 & $63.9 \%$ \\
\hline Decals for display in store windows & 37 & 61 & $60.7 \%$ \\
\hline $\begin{array}{l}\text { Recognition of business customers in program } \\
\text { ads or local media }\end{array}$ & 28 & 62 & $45.2 \%$ \\
\hline Plaques or other items for recognition & 25 & 61 & $41.0 \%$ \\
\hline Tours to renewable energy project sites & 22 & 61 & $36.1 \%$ \\
\hline $\begin{array}{l}\text { Installations on schools/renewable energy } \\
\text { education programs }\end{array}$ & 19 & 61 & $31.1 \%$ \\
\hline Compact fluorescents or efficiency products & 14 & 61 & $23.0 \%$ \\
\hline Protection from fuel-cost increases & 7 & 63 & $11.1 \%$ \\
\hline Discounts or promotions at local businesses & 5 & 61 & $8.2 \%$ \\
\hline Other & 3 & 58 & $5.2 \%$ \\
\hline Exemption from environmental fees & 1 & 62 & $1.6 \%$ \\
\hline
\end{tabular}

\section{Conclusions and Observations}

Based on our review of utility green pricing program data, there are a number of positive trends indicating that green pricing has the potential to substantially impact renewable energy development nationally. As of the end of 2002, about $400 \mathrm{MW}$ of renewable energy capacity was installed or planned as a result of utility green pricing programs. Since 1998, average annual growth in the number of green pricing programs has exceeded $40 \%$. As these offerings have expanded, there has been a fourfold increase in the number of green pricing participants. And renewable energy sales have reached nearly 900 million kWh annually, which represents an increase of nearly $60 \%$ from 2001 .

On the other hand, just more than $10 \%$ of utilities, representing about $20 \%$ of the national electricity customer base, offered green pricing at the end of 2002. And customer participation rates in existing green pricing programs remain low, averaging little more than $1 \%$ among all utilities and $2 \%$ for programs that have been in place for three or more years. These rates are well below the $50 \%$ to $70 \%$ of customers who in utility market research surveys indicate that they are willing to pay more for renewable energy (Farhar 1999). Furthermore, a relatively small number of programs account for the vast majority of renewable energy sales and customers - the top 10 performing programs are responsible for three-quarters of all green pricing participants and $80 \%$ of renewable energy sales.

Over the near term, there will likely be continued growth in the number of green pricing programs as state green pricing mandates take hold and currently planned programs are implemented. However, the overall impact that green pricing programs will have on stimulating future renewable energy development will depend on translating the success to date of a relatively few programs to the remainder of the utility industry. 


\section{References}

Bird, L. and B. Swezey, 2003a. Green Power Marketing in the United States: A Status Report (Sixth Edition), NREL/TP-620-35119. Golden, CO: National Renewable Energy Laboratory, October. http://www.eere.energy.gov/greenpower/pdf/35119.pdf

Bird, L. and B. Swezey, 2003b. Estimates of Renewable Energy Capacity Serving Green Power Markets in the United States. Golden, CO: National Renewable Energy Laboratory, February. http://www.eere.energy.gov/greenpower/new gp cap.shtml

Farhar, B., 1999. Willingness to Pay for Electricity from Renewable Resources: A Review of Utility Market Research, NREL/TP-550-26148. Golden, CO: National Renewable Energy Laboratory, July. http://www.eere.energy.gov/greenpower/farhar_26148.html

Harris, N., 2002. Powerful Choices III: A Survey of Retail Green Power Programs in the Pacific Northwest and Beyond. Portland, OR: Renewable Northwest Project, August. http://www.rnp.org/Resources/PC3Intro.html

Holt, E. and M. Holt, 2004. Green Pricing Resource Guide. Second Edition (Review Draft). Prepared for the American Wind Energy Association, Washington, D.C.

Lieberman, D., 2002. Green Pricing at Public Utilities: A How-To Guide Based on Lessons Learned to Date. San Francisco, CA: Center for Resource Solutions, October. http://www.resource-solutions.org/pdf/PRP.Green.Pricing.Report.10.29.02.pdf

Swezey, B. and L. Bird, 2001. Utility Green Pricing Programs: What Defines Success? NREL/TP-620-29831. Golden, CO: National Renewable Energy Laboratory, August. http://www.eere.energy.gov/greenpower/29831.pdf

Swezey, B. and L. Bird, 2000. Green Power Marketing in the United States: A Status Report (Fifth Edition), NREL/TP-620-28738. Golden, CO: National Renewable Energy Laboratory, August. http://www.eere.energy.gov/greenpower/pdf/28738.pdf

Swezey, B. and L. Bird, 1999. Information Brief on Green Power Marketing (Fourth Edition), NREL/TP-620-26901. Golden, CO: National Renewable Energy Laboratory, August. http://www.nrel.gov/analysis/emaa/brief $4 . h t m l$

Washington Department of Community, Trade and Economic Development (CTED) and Utilities Transportation Commission (UTC), 2002. Green Power Programs in Washington: A Report to the Legislature. Olympia, WA, December.

http://www.cted.wa.gov/DesktopDefault.aspx?tabid $=440$

Wiser, R., M. Bolinger, and E. Holt, 2000. Customer Choice and Green Power Marketing: A Critical Review and Analysis of Experience to Date, LBNL-46072. Berkeley, CA: Lawrence Berkeley National Laboratory, August. http://eetd.lbl.gov/ea/EMS/reports/46072.pdf

Wiser, R., S. Olson, L. Bird and B. Swezey, 2004. Utility Green Pricing Programs: A Statistical Analysis of Program Effectiveness, LBNL-54437. Berkeley, CA: Lawrence Berkeley National Laboratory, February. http://eetd.lbl.gov/ea/ems/reports/54437.pdf 


\section{Appendix A}

\section{Utility Green Pricing Program Questionnaire}

1. Utility name

2. Name of green power program (if you have multiple programs, please

fill out a separate form for each program)

3. Year program was launched

4. Which states is the program offered in?

\section{Participation}

5. In the table below, please provide participation data as of December 31, 2002. If data is provided for a different month (e.g., November) please specify

\begin{tabular}{|l|l|}
\hline Question & Response \\
\hline Number of current residential green power participants & \\
\hline Number of current nonresidential green power participants & \\
\hline Number of residential customers (or members) eligible to participate & \\
\hline Number of nonresidential customers (or members) eligible to participate & \\
\hline Is the program open to new customers? Yes/no & \\
\hline Number of customers on waiting list & \\
\hline Number of participants who have dropped out of the program this year & \\
\hline Minimum period of time residential customers must participate in program (e.g., 1 year) & \\
\hline Minimum period of time non-residential customers must participate (e.g., 2 years) & \\
\hline
\end{tabular}

6 . For programs that are jointly offered to multiple distribution cooperatives or municipal utilities, please indicate the highest overall participation rate achieved by a utility participating in the program.

Sales for the past year

7. In the table below, please indicate the sales of green power to customers during the previous 12 months. Please also indicate the top three nonresidential purchasers and the amount purchased during the past 12 months.

\begin{tabular}{|l|l|l|l|}
\hline Green power sales for most recent 12 months & Blocks & Block size & $\begin{array}{l}\text { KWh/year of } \\
\text { green power }\end{array}$ \\
\hline Green power sales to residential customers & & & \\
\hline Green power sales to nonresidential customers & & & \\
\hline Top 3 non-residential purchasers: & & & \\
\hline 1. & & & \\
\hline 2. & & & \\
\hline 3. & & & \\
\hline
\end{tabular}

Renewable Energy Supplies

8. Of the renewable energy used to supply your program, what percentage comes from the following?

Renewable projects owned or partly owned by your utility

Renewable energy purchases from others

Renewable certificate purchases 
9. In the table below, please indicate the type and amount of renewable resources used to supply your green pricing program during 2002.

\begin{tabular}{|l|l|l|l|}
\hline & $\begin{array}{l}\text { Nameplate } \\
\text { Capacity } \\
\text { Installed }(\mathrm{kW})\end{array}$ & $\begin{array}{l}\text { Energy Purchases } \\
\text { in 2002 }(\mathrm{kWh} / \mathrm{yr})\end{array}$ & $\begin{array}{l}\text { Nameplate Capacity } \\
\text { Planned }(\mathrm{kW})\end{array}$ \\
\hline Wind & & & \\
\hline PV & & & \\
\hline Solar Thermal & & & \\
\hline Landfill methane & & & \\
\hline Other Biomass & & & \\
\hline Hydro & & & \\
\hline Geothermal & & & \\
\hline
\end{tabular}

Premium

10. Please indicate the price premium charged for this green power product

11. Was there a change in the premium in 2002 ? Yes/no If so, why?

12. Are green power customers protected, by virtue of their green power purchase, from increases in fuel costs (i.e., natural gas) or increases in the price of conventional electricity? Yes/no If so, how?

Program Design and Implementation

13. Have you done your own customer research to aid in the design of your green power product or development of your marketing plan? Yes/no

14. Have you performed an evaluation of the program? Yes/no

15. In which of the following ways can customers sign up for your green power program? (check all that apply)

\begin{tabular}{|l|l|l|}
\hline Utility Web site & & By returning a mail-in card \\
\hline Checking a box on their electric bill & & Over the phone through the utility call center \\
\hline Sign up at special events & Other? & \\
\hline
\end{tabular}

\section{Marketing}

16. What percentage of the green power program budget was spent on marketing in 2002 ?

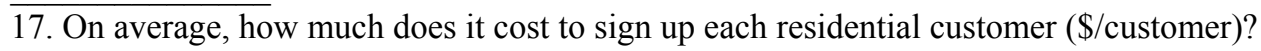


18. In the table below, please indicate how many times, if any, you have used the following marketing strategies for your green power program in the past year. For example, if bill inserts, direct mail, or newsletters were sent to 30,000 customers during the year, please indicate 30,000 . Also, please rank the cost-effectiveness of the strategy on a scale of 1 to 5 , with 5 being the most cost-effective strategy for obtaining customers.

\begin{tabular}{|c|c|c|}
\hline Strategy & Frequency & Cost-effectiveness \\
\hline Bill inserts & \# of inserts/year & \\
\hline Direct mail & $\#$ of mail pieces/year & \\
\hline $\begin{array}{l}\text { Utility newsletter that mentions green } \\
\text { power }\end{array}$ & \# of newsletters/year & \\
\hline Television & $\begin{array}{l}\text { \# of commercials } \\
\text { aired/year }\end{array}$ & \\
\hline Radio & \# of announcements/year & \\
\hline Newspapers & \# of ads/year & \\
\hline Telemarketing & \# of calls/year & \\
\hline Billboards & \# of billboards & \\
\hline Events & \# events/year & \\
\hline Publicity/feature stories (non-paid) & \# of articles/year & \\
\hline Other? & & \\
\hline
\end{tabular}

Value for Consumers

19. What other value-added products or services do you provide to your green power customers? Please check as many as are applicable.

\begin{tabular}{|l|l|l|l|}
\hline Compact fluorescents or efficiency products & & Decals for display in store windows & \\
\hline $\begin{array}{l}\text { Recognition of business customers in program } \\
\text { ads or local media }\end{array}$ & & $\begin{array}{l}\text { Installations on schools/renewable energy } \\
\text { education programs }\end{array}$ & \\
\hline Discounts or promotions at local businesses & & Plaques or other items for recognition & \\
\hline Newsletters that provide program updates & & Protection from fuel cost increases & \\
\hline Tours to renewable energy project sites & & Exemption from environmental fees & \\
\hline Other (please list) & \\
\hline
\end{tabular}

Confidentiality - Individual utility responses to this survey regarding customer, sales, and marketing information will be held confidential. Data will be used to prepare NREL's list of Top 10 utility green pricing programs and to provide aggregate industry data to the U.S. DOE and the general public.

Please e-mail or fax this questionnaire by Wednesday, January 15 to: Lori Bird, lori bird@nrel.gov, Fax (303) 384-7411. If questions, please call Lori Bird at (303) 384-7412. 


\section{Appendix B}

Table B-1: Utilities Offering Green Pricing Programs in 2002

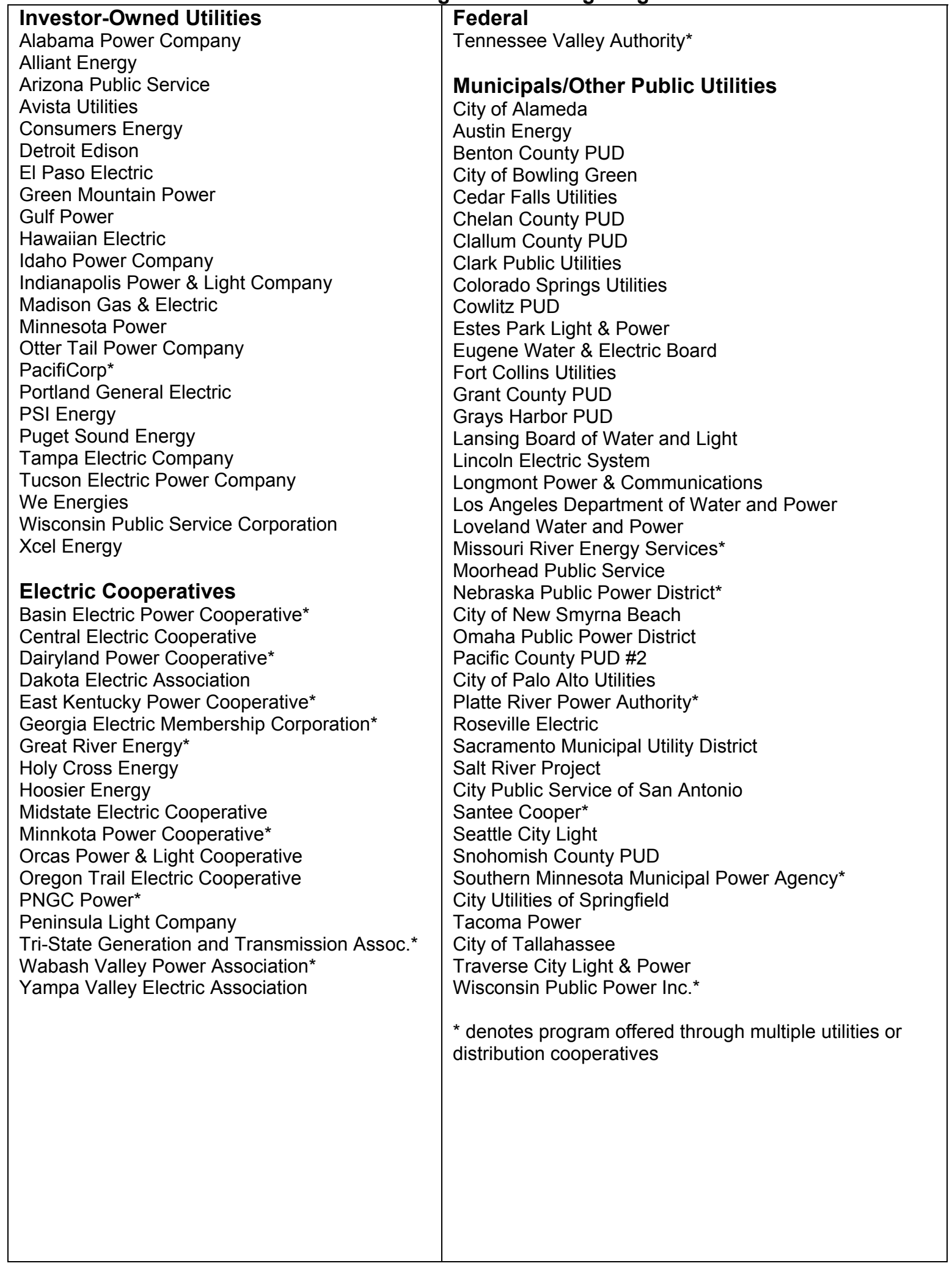




\section{Appendix C}

Table C-1: Green Pricing Program Renewable Energy Sales (as of December 2002)

\begin{tabular}{|c|c|c|c|c|}
\hline Rank & Utility & Resources Used & $\begin{array}{c}\text { Sales } \\
\text { (kWh/year) }\end{array}$ & $\begin{array}{c}\text { Sales } \\
\text { (Average } \\
\text { MW) }^{\mathrm{a}}\end{array}$ \\
\hline 1 & Austin Energy & $\begin{array}{l}\text { Wind, landfill gas, } \\
\text { solar }\end{array}$ & $251,520,000$ & 28.7 \\
\hline 2 & $\begin{array}{l}\text { Sacramento Municipal Utility } \\
\text { District }\end{array}$ & $\begin{array}{l}\text { Landfill gas, wind, } \\
\text { solar }\end{array}$ & $104,344,000^{b}$ & 11.9 \\
\hline 3 & Xcel Energy & Wind and solar & $103,739,000^{c}$ & 11.8 \\
\hline 4 & $\begin{array}{l}\text { Los Angeles Department of } \\
\text { Water and Power }\end{array}$ & $\begin{array}{l}\text { Wind and landfill } \\
\text { gas }\end{array}$ & $66,666,000^{d}$ & 7.6 \\
\hline 5 & Portland General Electric ${ }^{\mathrm{e}}$ & $\begin{array}{l}\text { Wind and } \\
\text { geothermal }\end{array}$ & $57,989,000$ & 6.6 \\
\hline 6 & PacifiCorp $^{e}$ & $\begin{array}{l}\text { Wind and } \\
\text { geothermal }\end{array}$ & $55,615,000$ & 6.3 \\
\hline 7 & Tennessee Valley Authority & $\begin{array}{l}\text { Wind, biomass, } \\
\text { landfill gas, solar }\end{array}$ & $35,955,000$ & 4.1 \\
\hline 8 & We Energies & $\begin{array}{l}\text { Landfill gas, wind, } \\
\text { hydro }\end{array}$ & $35,161,000$ & 4.0 \\
\hline 9 & Puget Sound Energy & Wind and solar & $20,334,000$ & 2.3 \\
\hline 10 & Madison Gas \& Electric & Wind & $15,593,000$ & 1.8 \\
\hline
\end{tabular}

${ }^{a}$ An "average megawatt" is a consistent measure of capacity equivalent that assumes the capacity operates continuously.

${ }^{\mathrm{b}}$ Includes an estimated 3 million $\mathrm{kWh}$ of generation from the 1.9 MW of PV installed through the PV Pioneers program.

${ }^{\mathrm{c}}$ Includes an estimated $175,000 \mathrm{kWh}$ of generation from the $100 \mathrm{~kW}$ of PV installed through the Renewable Energy Trust program.

${ }^{\mathrm{d}}$ Data for 2001 from program audit conducted by the Los Angeles City Controller, August 2002.

${ }^{\mathrm{e}}$ Marketed in partnership with Green Mountain Energy Company. 
Table C-2: Total Number of Customer Participants (as of December 2002)

\begin{tabular}{|c|c|c|c|}
\hline Rank & Utility & Program Name(s) & Participants \\
\hline 1 & $\begin{array}{l}\text { Los Angeles Department of Water and } \\
\text { Power }\end{array}$ & $\begin{array}{l}\text { Green Power for a Green } \\
L A\end{array}$ & $72,732^{\mathrm{a}}$ \\
\hline 2 & Xcel Energy & $\begin{array}{l}\text { Windsource } \\
\text { Renewable Energy Trust }\end{array}$ & $32,600^{b}$ \\
\hline 3 & PacifiCorp $^{c}$ & $\begin{array}{l}\text { Blue Sky } \\
\text { Renewable Usage } \\
\text { Salmon-Friendly }\end{array}$ & 20,028 \\
\hline 4 & Portland General Electric ${ }^{c}$ & $\begin{array}{l}\text { Clean Wind Power } \\
\text { Renewable Usage } \\
\text { Salmon-Friendly }\end{array}$ & 19,623 \\
\hline 5 & Sacramento Municipal Utility District & $\begin{array}{l}\text { Greenergy } \\
\text { PV Pioneers }\end{array}$ & $19,172^{d}$ \\
\hline 6 & We Energies & Energy for Tomorrow & 11,014 \\
\hline 7 & Alliant Energy & Second Nature & 7,280 \\
\hline 8 & Austin Energy & GreenChoice & 6,725 \\
\hline 9 & Tennessee Valley Authority & Green Power Switch & 6,487 \\
\hline 10 & Wisconsin Public Service & $\begin{array}{l}\text { SolarWise for Schools } \\
\text { NatureWise }\end{array}$ & $5,644^{\mathrm{e}}$ \\
\hline
\end{tabular}

${ }^{\text {a }}$ Includes 41,833 lifeline/low-income customers that have signed up for green power but do not pay a premium.

${ }^{5}$ There were 9,420 participants in the Renewable Energy Trust program as of December 2002.

About $20 \%$ of these customers also participate in the Windsource program.

${ }^{c}$ Marketed in partnership with Green Mountain Energy Company.

${ }^{\mathrm{d}}$ About 800 customers participate in the PV Pioneers program.

${ }^{\mathrm{e}}$ A total of 1,048 customers participate in the NatureWise program. There are 204 customers that participate in both of the utility's green power programs. 
Table C-3: Customer Participation Rate (as of December 2002)

\begin{tabular}{|c|c|c|c|c|}
\hline Rank & Utility & Program Name(s) & $\begin{array}{c}\text { Customer } \\
\text { Participation } \\
\text { Rate } \\
\end{array}$ & $\begin{array}{c}\text { Program } \\
\text { Start } \\
\text { Date } \\
\end{array}$ \\
\hline 1 & Moorhead Public Service & Capture the Wind & $5.8 \%$ & 1998 \\
\hline 2 & Orcas Power \& Light & Green Power & $5.5 \%$ & 1999 \\
\hline 3 & $\begin{array}{l}\text { Los Angeles Department of } \\
\text { Water and Power }\end{array}$ & $\begin{array}{l}\text { Green Power for a Green } \\
L A\end{array}$ & $5.2 \%^{a}$ & 1999 \\
\hline 4 & Holy Cross Energy & $\begin{array}{l}\text { Wind Power Pioneer } \\
\text { Local Renewable Energy } \\
\text { Pool }\end{array}$ & $4.9 \%$ & 1998 \\
\hline 5 & Central Electric Cooperative $^{\mathrm{b}}$ & Green Power & $3.7 \%$ & 1999 \\
\hline 6 & Madison Gas \& Electric & Wind Power Program & $3.6 \%$ & 1999 \\
\hline 6 & $\begin{array}{l}\text { Sacramento Municipal Utility } \\
\text { District }\end{array}$ & Greenergy, PV Pioneers & $3.6 \%$ & 1997 \\
\hline 8 & Preston Public Utilities ${ }^{c}$ & Wind Power & $3.4 \%$ & 2000 \\
\hline 9 & $\begin{array}{l}\text { Cass County Electric } \\
\text { Cooperative }\end{array}$ & Infinity Wind Energy & $3.1 \%$ & 1999 \\
\hline 10 & Cedar Falls Utilities & $\begin{array}{l}\text { Wind Energy Electric } \\
\text { Project }\end{array}$ & $3.0 \%$ & 1999 \\
\hline 10 & $\begin{array}{l}\text { Eugene Water \& Electric } \\
\text { Board }\end{array}$ & EWEB Wind Power & $3.0 \%$ & 1999 \\
\hline
\end{tabular}

${ }^{a}$ Includes lifeline/low-income customers that have signed up for green power but do not pay a premium.

${ }^{b}$ Supplied by the Pacific Northwest Generating Cooperative.

${ }^{\mathrm{c}}$ Supplied by Southern Minnesota Municipal Power Agency.

${ }^{\mathrm{d}}$ Supplied by Minnkota Power Cooperative. 
Table C-4: Price Premium Charged for New, Customer-Driven Renewable Power ${ }^{\mathrm{a}}$ (as of December 2002)

\begin{tabular}{|c|l|c|c|}
\hline Rank & Utility & Resources Used & Premium \\
\hline $\mathbf{1}$ & $\begin{array}{l}\text { Clallam County Public Utility } \\
\text { District }\end{array}$ & Landfill gas & $0.70 \phi / \mathrm{kWh}$ \\
\hline $\mathbf{2}$ & Roseville Electric & $\begin{array}{c}\text { Reinjected geothermal and } \\
\text { solar }\end{array}$ & $1.00 \phi / \mathrm{kWh}$ \\
\hline $\mathbf{2}$ & $\begin{array}{l}\text { Sacramento Municipal Utility } \\
\text { District }\end{array}$ & Landfill gas, hydro, wind & $1.00 \phi / \mathrm{kWh}$ \\
\hline $\mathbf{4}$ & $\begin{array}{l}\text { Pacific County Public Utility } \\
\text { District }\end{array}$ & Wind and hydro & $1.05 \phi / \mathrm{kWh}$ \\
\hline $\mathbf{5}$ & Austin Energy & Wind, solar, landfill gas & $1.08 \phi / \mathrm{kWh}$ \\
\hline $\mathbf{6}$ & Eugene Water and Electric Board & Wind & $1.30 \phi / \mathrm{kWh}$ \\
\hline $\mathbf{7}$ & City of Bowling Green (Ohio) & Small hydro and solar & $1.35 \phi / \mathrm{kWh}$ \\
\hline $\mathbf{7}$ & Dakota Electric Association & Wind & $1.35 \phi / \mathrm{kWh}$ \\
\hline $\mathbf{9}$ & Clark Public Utilities & Wind and solar & $1.50 \phi / \mathrm{kWh}$ \\
\hline $\mathbf{9}$ & Great River Energy & Wind & $1.50 \phi / \mathrm{kWh}$ \\
\hline $\mathbf{9}$ & Oregon Trail Electric Cooperative & Wind & $1.50 \phi / \mathrm{kWh}$ \\
\hline \hline
\end{tabular}

a Includes only programs that have installed - or announced firm plans to install or purchase power from - new renewable resources.

${ }^{\mathrm{b}}$ Price premium for customers who signed up for Phase 2 of program. Customers are exempt from fuel charges.

${ }^{c}$ Suggested retail price for member distribution cooperatives.

${ }^{\mathrm{d}}$ Adjusted to reflect the cost of $100 \%$ new wind power. 


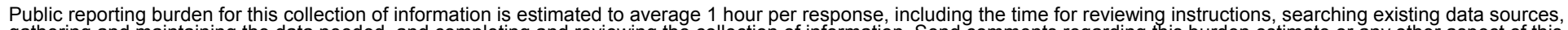

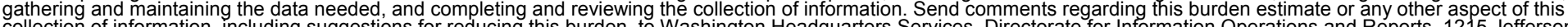

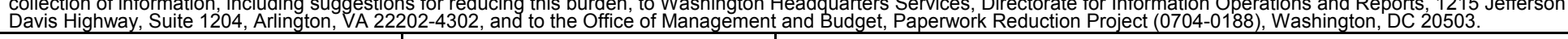

\begin{tabular}{|l|l|l} 
1. AGENCY USE ONLY (Leave blank) & $\begin{array}{l}\text { 2. REPORT DATE } \\
\text { February 2004 }\end{array}$ & $\begin{array}{l}\text { 3. REPORT TYPE AND DATES COVERED } \\
\text { Technical Report - Analysis }\end{array}$
\end{tabular}

4. TITLE AND SUBTITLE

Utility Green Pricing Programs: Design, Implementation, and Consumer Response

6. AUTHOR(S)

Lori Bird, Blair Swezey, Jørn Aabakken

7. PERFORMING ORGANIZATION NAME(S) AND ADDRESS(ES)

National Renewable Energy Laboratory

1617 Cole Blvd.

Golden, CO 80401-3393

9. SPONSORING/MONITORING AGENCY NAME(S) AND ADDRESS(ES)
5. FUNDING NUMBERS

TA: AS73.8004

8. PERFORMING ORGANIZATION REPORT NUMBER

NREL/TP-620-35618

10. SPONSORING/MONITORING AGENCY REPORT NUMBER

11. SUPPLEMENTARY NOTES

12a. DISTRIBUTION/AVAILABILITY STATEMENT

National Technical Information Service

U.S. Department of Commerce

5285 Port Royal Road

Springfield, VA 22161

13. ABSTRACT (Maximum 200 words)

The term green pricing refers to programs offered by utilities in traditionally regulated electricity markets, which allow customers to support the development of renewable energy sources by paying a small premium on their electric bills. Since the introduction of the concept in the United States, the number of unique utility green pricing programs has expanded from just a few programs in 1993 to more than 90 in 2002 . About $10 \%$ of U.S. utilities offered a green pricing option to about 26 million consumers by the end of 2002. This report provides: 1) aggregate industry data on consumer response to utility programs, which indicate the collective impact of green pricing on renewable energy development nationally; and 2) market data that can be used by utilities as a benchmark for gauging the relative success of their green pricing programs. Specifically, the paper presents current data and trends in consumer response to green pricing, as measured by renewable energy sales, participants, participation rates, and new renewable energy capacity supported. It presents data on various aspects of program design and implementation, such as product pricing, ownership of supplies, retention rates, marketing costs, the effectiveness of marketing techniques, and methods of enrolling and providing value to customers.

\section{SUBJECT TERMS}

analysis, green pricing, consumer response, green pricing programs, renewable energy supplies, green energy, customer participation rates, renewable energy capacity installations, price premiums, green power products, green power markets, utility green pricing programs, Lori Bird, Blair Swezey, Jørn Aabakken.

\begin{tabular}{|c|c|c|}
\hline $\begin{array}{l}\text { 17. SECURITY CLASSIFICATION } \\
\text { OF REPORT } \\
\text { Unclassified }\end{array}$ & $\begin{array}{l}\text { 18. SECURITY CLASSIFICATION } \\
\text { OF THIS PAGE } \\
\text { Unclassified }\end{array}$ & $\begin{array}{l}\text { 19. SECURITY CLASSIFICATION } \\
\text { OF ABSTRACT } \\
\text { Unclassified }\end{array}$ \\
\hline
\end{tabular}

NSN 7540-01-280-5500
15. NUMBER OF PAGES

16. PRICE CODE

20. LIMITATION OF ABSTRACT

UL 